\title{
PROFIL KELOMPOK TANI MAKMUR ABADI DALAM PENGEMBANGAN WISATA PETIK APEL
}

\author{
Muhammad Shivana R \\ Hardika \\ Ahmad Mutadzakir \\ Jurusan Pendidikan Luar Sekolah FIP Universitas Negeri Malang \\ Jalan Semarang 5 Malang \\ E-mail: shevanme@gmail.com
}

\begin{abstract}
Profile of Farmers Group of Makmur Abadi in Tourism Development of Picking Apples. Makmur Abadi farmers group in is the embodiment of a container that is required of farmer's, farmer's groups develop tourism pick apples, many of which have not been revealed how organizing patterns that exist in Makmur Abadi farmer groups in developing tourism. This study aims to describe the pattern of organizing in Makmur Abadi farmer group in developing tours include: the Division of labor, the pattern of leadership, how to increase active members. This research used the qualitative case study research.
\end{abstract}

Keywords: farmer groups, development of tourism, picking apples

\begin{abstract}
Abstrak: Profil Kelompok Tani Makmur Abadi dalam Pengembangan Wisata Petik Apel. Kelompok Tani Makmur Abadi adalah perwujudan dari sebuah wadah yang diperlukan para petani, kelompok tani ini mengembangkan wisata petik apel, banyak yang belum terungkap bagaimana pola pengorganisasian yang ada di Kelompok Tani Makmur Abadi dalam mengembangkan wisata. Penelitian ini bertujuan untuk mendeskripsikan pola pengorganisasian di Kelompok Tani Makmur Abadi dalam mengembangkan wisata meliputi: pembagian kerja, pola kepemimpinan, cara peningkatan keaktifan anggota. Penelitian ini menggunakan penelitian kualitatif studi kasus.
\end{abstract}

Kata kunci: kelompok tani, pengembangan wisata, petik apel

Pembangunan agraris di Indonesia menitikberatkan pada peningkatan kesejahteraan hidup petani di bidang ekonomi, pendidikan dan kesehatan. Sektor pertanian mempunyai peranan strategis dalam struktur pembangunan perekonomian nasional. Pertanian merupakan sektor yang memiliki peranan signifikan bagi perekonomian Indonesia. Para petani atau tenaga kerja pertanian di Indonesia menghadapi beragam permasalahan dalam peningkatan kesejahteraan hidup. Sektor pertanian di Indonesia dianggap penting terlihat dari peranan sektor pertanian terhadap penyediaan lapangan kerja, penyediaan pangan, penyumbang devisa negara melalui ekspor dan sebagainya.
Sektor pertanian sebagai salah satu pendapatan terbesar dari negara Indonesia.

Petani memainkan peranan sebagai inti dalam pembangunan pertanian. Petanilah yang memelihara tanaman dan menentukan bagaimana usaha taninya harus dimanfaatkan.

Petani yang harus mempelajari dan menerapkan metode-metode baru yang diperlukan untuk membuat usaha taninya lebih produktif. Kekayaan alam dan keberagaman bangsa Indonesia memang menyimpan banyak potensi sekaligus mempunyai kearifan lokal sehingga memberikan peluang untuk membangun kepariwisataan agar Indonesia lebih dipandang dunia. 
Pengorganisasian masyarakat ditujukan agar mereka mampu melakukan kegiatan secara struktur dan berdaya. Pengorganisasian memiliki tiga dimensi Winardi (2003:20) sebagai berikut: (a) organisasi itu sendiri memiliki suatu bentuk-suatu konfigurasi yang melukiskan herarki manajemen dan saluran-saluran komunikasi formal, (b) melalui proses pengorganisasian tugas-tugas dirumuskan/ditetapkan dan pekerjaan-pekerjaan individual distruktur, (c) sebuah falsafah organisasi, mempengaruhi upaya dengan apa koordinasi di capai.

Pengorganisasian masyarakat merupakan proses dalam menghimpun masyarakat untuk membuat kelompok yang terstruktur, memiliki tujuan dan pembagian tugas yang jelas serta bertanggungjawab atas setiap kewenangan yang dimiliki. Begitu pula dengan kelompok tani yang ada di desa Tulungrejo, dalam pelaksanaan kegiatan kelompok tani di desa Tulungrejo membutuhkan suatu pengorganisasian untuk mengatur anggota dalam mengembangkan wisata.

Setiap kegiatan di pedesaan tidak terlepas dari adanya partisipasi kelompok, yaitu diantaranya Kelompok Tani Makmur Abadi yang ada di desa Tulungrejo, merupakan salah satu organisasi masyarakat dalam bidang pertanian. Kelompok Tani Makmur Abadi merupakan suatu kelompok tani yang terdapat di desa Tulungrejo tepatnya di jalan Diponegoro 24 Tulungrejo Kecamatan Bumi Aji Kota Batu.

Pendidikan Luar Sekolah berfungsi mengembangkan potensi peserta didik dengan penekanan pada penguasaan pengetahuan dan keterampilan fungsional serta pengembangan sikap dan kepribadian profesional. Pola pengorganisasian anggota Kelompok Tani Makmur Abadi dalam mengembangkan desa wisata belum banyak terungkap, padahal di sisi lain tahap pengorganisasian di desa Tulungrejo bisa berhasil dan dapat meningkatkan taraf hidup, sehingga bermanfaat bagi pemberdayaan masyarakat pada daerah-daerah pedesaan lainnya di Indonesia terutama di kota Batu.

\section{METODE}

Pendekatan yang digunakan dalam rangka penelitian ini adalah penelitian kualitatif dengan rancangan penelitian studi kasus. Cresswell
(2015:1) "penelitian kualitatif adalah sebuah pendekatan penelitian yang diselenggarakan dalam setting alamiah, memerankan peneliti sebagai instrumen pengumpul data, menggunakan analisis induktif, dan berfokus pada makna menurut perspektif partisipan".

Jenis penelitian yang digunakan adalah studi kasus, menggunakan jenis penelitian ini karena, (1) membutuhkan data yang mendetail sehingga harus menggunakan pertanyaan-pertanyaan tentang bagaimana dan mengapa agar bisa mengembangkan pertanyaan lain untuk mendapatkan data yang terperinci, (2) pertanyaan mengapa dan bagaimana digunakan untuk menggali informasi yang belum diketahui peneliti sebelumnya sehingga apabila menggunakan kuantitatif dengan angket atau kuesioner maka peneliti tidak akan mendapatkan data yang rinci dan mendalam, (3) ada ketersediaan waktu dan sumber daya yang cukup untuk mengumpulkan data yang melimpah, (4) laporan penelitian ditulis dalam bentuk uraian/ esai, (5) mendapat dukungan dari beberapa informan apabila peneliti ingin menggali informasi yang mendetail berkaitan dengan kasus yang diteliti.

Data penelitian ini, teknik dokumentasi juga digunakan untuk mendapatkan data yang meliputi struktur lembaga, profil Kelompok Tani Makmur Abadi, gambaran umum kegiatan pengorganisasian kelompok tani makmur. Berdasarkan studi dokumentasi yang dilakukan, mendapatkan informasi tentang profil Kelompok Tani Makmur Abadi di desa tulungrejo kota Batu.

Tempat penelitian berada di Kelompok Tani Makmur Abadi jalan Diponegoro 24 desa Tulungrejo, kecamatan Bumiaji kota Batu. Alasan peneliti memilih lokasi ini, karena keberhasilan Kelompok Tani Makmur Abadi dalam mengorganisir kelompok masyarakat desa dan mengembangkan desa wisata di desa Tulungrejo tersebut yang nantinya dapat menjadi acuan kelompok tani di Kota Batu.

Subyek utama penelitian adalah ketua, sekretaris dan anggota Kelompok Tani Makmur Abadi. Alasan memilih subjek penelitian tersebut adalah karena pengetahuan memiliki peran penting dalam memajukan kelompok dan mengetahui banyak tentang kelompok

Teknik analisis data pada penelitian ini menggunakan analisis data kualitatif. Analisis 
data merupakan proses berkelanjutan yang membutuhkan refleksi terus-menerus terhadap data, mengajukan pertanyaan analitis, dan menulis catatan singkat sepanjang penelitian (Cresswell, 2015: 250).

Teknik analisis data yang umum di dalam penelitian kualitatif adalah teknik analisis spiral. Untuk melakukan analisis data, peneliti terlibat dalam suatu proses dinamis yang bergerak dari satu lingkaran ke lingkaran berikutnya dan bukan proses linier yang sudah baku.

Proses dimaksud meliputi: pengelolaan data yang menghasilkan unit atau fail, membaca dan membuat catatan yang menghasilkan catatan-catatan berdasarkan lintas pertanyaan dan refleksi, mendeskripsikan, mengklasifikasi, menginterpretasi yang menghasilkan konteks, kategori, dan komparasi, dan menyajikan, menvisualisasikan yang menghasilkan matriks, diagram pohon, ataupun proposisi (Creswell, 2015:255) Tahapan analisis data yang dilakukan oleh peneliti dalam penelitian tersebut disajikan dalam Gambar 1.

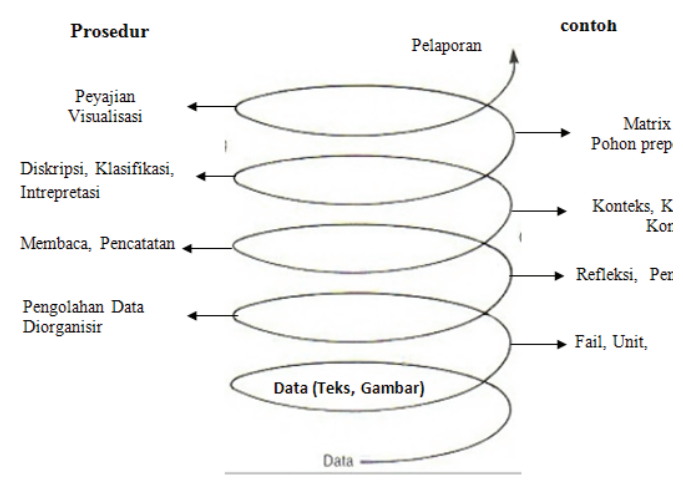

Gambar 1 Analisis Spiral

Tahap penelitian dilakukan melalui tiga tahap, yaitu: tahap pra-lapangan, tahap pelaksanaan penelitian, tahap pasca pelaksanaan. Pada tahap pralapangan, menyusun rancangan penelitian secara matang, peneliti terlebih dahulu melakukan studi pendahuluan (survey) ke Kelompok Tani Makmur Abadi untuk memperoleh gambaran secara umum tentang lokasi penelitian, studi pendahuluan yang dilakukan petani mulai tanggal 26 Februari 2016 sampai 20 Maret 2016 selanjutnya mempelajari setiap topik penelitian dengan mengamati kondisi di lapangan yaitu pada Kelompok Tani Makmur
Abadi Desa Tulungrejo Bumiaji Kota Batu. Topik penelitian kemudian ditentukan dengan cara memilih topik yang paling tepat dan sesuai dengan kondisi di lapangan dibantu dan diarahkan oleh dosen pembimbing, merancang usulan, mengurus perizinan, memilih dan memanfaatkan informan yang ada serta menyiapkan perlengkapan penelitian.

Tahap pelaksanaan penelitian, dengan memasuki lokasi yang menjadi objek penelitian yaitu di Kelompok Tani Makmur Abadi di Desa Tulungrejo Kecamatan Bumiaji Kota Batu. Penelitian dilakukan selama dua bulan lebih dimulai dari bulan April sampai Mei di kantor Kelompok Tani Makmur Abadi dan di kebun. Membuat pertanyaan berupa pedoman wawancara yang disesuaikan dengan fokus penelitian, dilanjutkan melakukan pendekatan terhadap subyek penelitian secara mendalam dengan menggunakan teknik wawancara, observasi, dan dokumentasi dengan melibatkan pengurus kelompok tani dan anggota kelompok tani.

Pada tahap pasca penelitian ini peneliti menganalisis dan membuat laporan penelitian yang dinyatakan sudah cukup, kegiatan yang dilakukan pengolahan data melalui proses reduksi data, penyajian data, penarikan kesimpulan dan verifikasi. Data yang sudah dipaparkan selanjutnya oleh peneliti dilakukan uji keabsahan data atau validasi data. Pada tahap ini peneliti malakukan uji keabsahan dengan melakukan uji kredibilitas dengan cara triangulasi. Proses triangulasi dilakukan oleh peneliti dengan cara melakukan pengecekan data dari berbagai sumber.

Selanjutnya peneliti melakukan konsultasi kepada dosen pembimbing, terakhir peneliti adalah melaporkan hasil temuan atau hasil penelitian yang telah dilakukan. Proses pelaporan hasil penelitian disesuaikan dengan sistematika penulisan laporan penelitian yang sudah ditentukan oleh Universitas Negeri Malang.

Untuk pengecekan keabsahan data, peneliti menggunakan triangulasi, pengecekan anggota, dan pemeriksaan/diskusi teman sejawat. Triangulasi adalah pemeriksaan/pengecekan keabsahan data dengan menggunakan: (1) banyak sumber data, (2) banyak metode/teknik pengumpulan untuk konfirmasi data, (3) banyak waktu, dan (4) banyak penyidik atau investor. 
Triangulasi sumber berarti membandingkan dan mengecek balik informasi atau data yang diperoleh dari sumber/informan yang berbeda. Triangulasi metode/teknik berarti membandingkan dan mengecek balik informasi atau data yang diperoleh dari metode pengumpulan data yang berbeda-beda. Triangulasi waktu berarti peneliti melakukan pengecekan data dengan waktu yang berbeda. Triangulasi penyidik/investor berarti membandingkan dan mengecek informasi atau data yang diperoleh oleh peneliti satu dengan yang lain (Ulfatin 2013:234).

\section{HASIL DAN PEMBAHASAN}

\section{Hasil}

Kelompok Tani Makmur Abadi menggunakan bentuk pembagian kerja dalam menjalankan setiap program yang ada, hal ini bertujuan agar dalam pelaksanaan anggota dapat terfokus dengan pekerjaan yang diberikan oleh kelompok. Sejarah terbentuknya Kelompok Tani Makmur Abadi sendiri tidak terlepas dari keinginan dari petani untuk memiliki peran masing-masing dalam mengembangkan pertanian mereka juga karena para petani menginginkan sebuah wadah dalam menjalankan pertanian petik apel.

Pada dasarnya memang dibentuknya Kelompok Tani Makmur Abadi merupakan suatu inisiatif yang dimiliki oleh petani, karena mereka merasa pertanian yang mereka lakukan kurang efektif dalam hasilnya, kemudian ingin lebih mengembangkan pertanian apel yang merupakan ikon dari kota Batu, selain itu juga mereka membutuhkan pembagian kerja masing-masing yang jelas untuk meningkatkan hasil pertanian mereka.

Tujuan yang mereka inginkan dengan dibentuknya Kelompok Tani Makmur Abadi agar mereka bisa belajar mengorganisasi. Pembagian kerja yang dilakukan oleh Kelompok Tani Makmur Abadi memang tidak bisa terlepas dari proses pengorganisasian yang dilakukan Kelompok Tani Makmur Abadi kepada petani, mulai dari bagaimana menjadikan kualitas apel yang baik dan melakukan kordinasi secara langsung ke petani melalui pertemuan-pertemuan yang dilakukan.

Pembagian-pembagian kerja yang diberikan kelompok ke anggota juga sangat berperan dalam memajukan pertanian apel yang sama dulunya setiap satu bulan sekali diadakan pelatihan sekolah lapang kemudian pelatihan-pelatihan lainnya juga diberikan di Kelompok Tani Makmur Abadi, hal ini diadakan untuk menunjang pengetahuan petani, dan juga pelatihan mengenai organisasi untuk meningkatkan pengetahuan tentang menjalankan tugas dengan baik.

Peran yang ada di Kelompok Tani Makmur Abadi sudah saling melengkapi untuk keberlangsungan kebaikan Kelompok Tani Makmur Abadi yang menaungi para petani apel yang ada di desa Tulungrejo. Peran petani disini menghasilkan kualitas apel yang baik sehingga laku dalam pasaran dan mengelola kebun dengan baik sehingga perkebunan mereka bisa dipakai untuk tempat wisata petik kebun, selanjutnya peran dari kelompok atau lembaga disini berperan dalam memfasilitasi kebutuhan yang diperlukan oleh petani selain itu juga kelompok berperan dalam penyelesaian masalah yang dialami petani.

Kesimpulan yang terakhir adalah kesesuaian program yang diberikan kelompok ke petani secara umum sudah sesuai karena selama ini program yang diberikan ke petani sudah banyak membantu petani dalam mengembangkan pertanian apel. Dalam proses pengorganisasian ketua memiliki peran untuk memimpin suatu organisasi serta mengarahkannya. Pemimpin memiliki peran yang penting dalam hal mengorganisasi setiap anggota mempengaruhi dan memotivasi anggota. Bentuk kepemimpinan yang ada di Kelompok Tani Makmur Abadi menggunakan model kepemimpinan demokrasi, ini dapat dilihat setiap kegiatan yang dilakukan.

Proses menghimpun petani untuk masuk dalam Kelompok Tani Makmur Abadi memang tidaklah mudah karena dulu mereka petani sekedar mengetahui ada kelompok dan mengira bila masuk kelompok itu selalu mendapat bantuan, akan tetapi pada kenyataannya tidak selalu ada bantuan yang datang, sehingga lambat laun sebagian petani yang ada di kelompok keluar dengan sendirinya yang merasa tidak mendapat manfaat akan tetapi bagi petani yang mengerti akan manfaat mengikuti kelompok mereka tetap bertahan.

Peran ketua dari Kelompok Tani Makmur Abadi dirasa diperlukan untuk memberikan pemahaman lagi ke petani, memberitahu manfaat 
jika masuk dan saling bekerjasama dalam kelompok. Proses pengontrolan yang dilakukan Kelompok Tani Makmur Abadi biasanya dilakukan secara langsung oleh ketua dan pengurus Kelompok Tani Makmur Abadi dengan biasanya mengecek secara langsung ke lokasi yang serupa wisata petik apel, mereka mengecek setiap hari kesiapan kebun yang akan digunakan untuk menjadi tempat wisata petik apel.

Pertemuan-pertemuan setiap minggu dulunya juga sering dilakukan kelompok untuk membahas segala hal yang dialami selama satu minggu, namun pada saat ini pertemuan tersebut sudah jarang dilakukan kelompok karena melihat kesibukankesibukan dari petani.

Koordinasi memang sangat diperlukan dalam suatu kelompok dalam menjalankan roda organisasi. Hal ini berkaitan dengan bagaimana terlaksananya program kerja yang dilakukan nantinya. Kelompok Tani Makmur Abadi juga selalu melakukan kordinasi keanggota baik itu dilakukan pada saat pertemuan maupun di kebun. Kelompok Tani Makmur Abadi juga berkoordinasi berdasarkan unit-unit yang ada di kelompok, jadi mereka melakukan koordinasi berdasarkan unit yang mereka masuki.

Kelompok Tani Makmur Abadi selain berfokus pada wisata petik apel akan tetapi tidak lupa mengedepankan bagaimana memberdayakan petani itu sendiri untuk menunjang kemampuan para petani dalam mengembangkan dan mengelola wisata petik apel. Peran Kelompok Tani Makmur Abadi terlihat cukup aktif untuk memenuhi kebutuhan yang diperlukan kelompok.

Pelibatan anggota Kelompok Tani Makmur Abadi dalam mengembangkan wisata petik apel ini memang bisa dilakukan oleh kelompok, namun peran aktif anggota kelompok atau petani juga menjadi penentu pelayanan wisata petik apel tersebut.

Kelompok juga mengikutkan anggota dalam pelatihan-pelatihan yang di ikuti kelompok dan kelompok kadang juga mengajak para anggota untuk studi banding ke tempat kelompok tani lain dan pengelolaan wisata lain yang bertujuan untuk mendapatkan ilmu baru dari studi banding tersebut. Hal-hal tersebut memang bertujuan untuk lebih meningkatkan keaktifan para anggota kelompok yang nantinya dapat memajukan wisata petik apel tersebut disamping itu juga demi memajukan Kelompok Tani Makmur Abadi dan bisa dijadikan sebagai contoh kelompok tani di kota Batu.

\section{Pembahasan}

Kelompok Tani Makmur Abadi dimulai karena mereka dulunya memang membutuhkan apa itu yang dinamakan sebuah wadah yang dapat menaungi mereka yaitu petani apel, karena selama ini petani sendiri-sendiri mereka bertani merasa kesulitan dengan banyaknya permasalahan mereka hadapi, selain itu Kelompok Tani Makmur Abadi untuk mengatasi permasalahan dan mengayomi lagi kebutuhan para petani sebagai wadah pengembangan pertanian apel dengan membuat unit-unit yang disesuaikan dengan kebutuhan dari petani apel itu sendiri.

Menurut Mardikanto (dalam Setiana 2005:58) yang dimaksud kelompok adalah himpunan atau kesatuan manusia yang hidup bersama sehingga terdapat hubungan timbal balik dan saling berpengaruh-mempengaruhi serta memiliki kesadaran untuk saling tolong-menolong.

Kelompok Tani Makmur Abadi menggunakan bentuk pembagian kerja dalam menjalankan setiap program yang ada, hal ini bertujuan agar dalam pelaksanaan anggota dapat terfokus dengan pekerjaan yang diberikan oleh kelompok.

Pembagian kerja yang dilakukan dalam Kelompok Tani Makmur Abadi juga disesuaikan dengan kebutuhan dari petani itu sendiri. Pembagian kerjanya meliputi dari ketua, sekretaris, bendahara kemudian unit-unit yang ada di Kelompok Tani Makmur Abadi seperti unit wisata, unit saprotan, unit usaha, simpan pinjam dan unit pupuk.

Para petani dipersilahkan untuk masuk ke unit-unit tersebut berdasarkan keinginan dari petani, sehingga dalam pelaksanaan program bisa terlibat secara maksimal.

Menurut Fattah (2013:72) pembagian tugas adalah membagi seluruh beban kerja menjadi kegiatan-kegiatan yang dapat dilaksanakan oleh perseorangan atau perkelompok, pada hal ini bahwa orang-orang yang akan diserahi tugas harus didasarkan pada kualifikasi, tidak dibebani terlalu berat dan juga tidak terlalu ringan.

Dalam hal ini pendapat diatas juga ditegaskan oleh Hasibuan (2007:33) Pembagian kerja yaitu informasi tertulis yang menguraikan tugas dan 
tanggung jawab, kondisi pekerjaan, hubungan pekerjaan, dan aspek-aspek pekerjaan pada suatu jabatan tertentu dalam organisasi. Pembagian kerja yang ada dalam kelompok tani juga tidak bisa terlepas dari bagaimana pengorganisasian yang dilakukan oleh kelompok kepada anggota maupun petani. Pembagian kerja yang efektif dilakukan dengan melihat bagaimana pengorganisasiannya, seperti halnya di Kelompok Tani Makmur Abadi.

Wisata petik apel yang dikembangkan oleh Kelompok Tani Makmur Abadi dikembang berdasarkan potensi yang dimiliki desa Tulungrejo, dimana yang dulunya kebun apel yang ada di desa Tulungrejo kurang ada pemeliharaan dan terkesan sekedar memanen, akan tetapi sejak didirikannya Kelompok Tani Makmur Abadi perkebunan bisa terawat sehingga bisa dijadikan tempat wisata. Menurut Fandeli (2001:61) menyatakan "wisata alam dapat dikelompokkan menjadi wisata alam, wisata pertanian dan wisata pedesaan". proses pengorganisasian tidak luput dari yang namanya seorang ketua atau pemimpin dalam memimpin suatu perkumpulan yang ada dalam mengarahkan. Pemimpin memiliki peran yang penting dalam halnya mengorganisasi setiap anggota dan dapat mempengaruhi juga memotivasi anggota. Permasalahan pertama muncul tentang bagaimana cara mengaktifkan anggota untuk semakin aktif dalam mengembangkan kelompok dan wisata. Untuk mengatasi itu kelompok tani memiliki inisiatif yaitu dengan diadakannya pertemuanpertemuan untuk membahas permasalahan yang menjadikan anggota kurang aktif.

Peningkatan keaktifan anggota yang dilakukan di kelompok tani yang selanjutnya yaitu dengan memberikan umpan berupa bantuan kepada para petani bentuknya seperti pemberian bibit dan obat-obatan kepada para petani, selain itu ketua kelompok sambil memberikan motivasi dan memberi pengarahan agar anggota kelompok semakin aktif di kelompok tani makmur abadi dalam mengembangkan wisata petik apel.

Menurut Therry (dalam Thoha 2013:15), merumuskan bahwa kepemimpinan itu adalah aktivitas untuk mempengaruhi orang-orang agar diarahkan mencapai tujuan organisasi. Peran ketua kelompok disini sesuai dengan pendapat yang paparkan oleh Therry bahwasanya ketua berperan untuk memengaruhi anggotanya untuh mengarahkan mencapai tujuan.

Kelompok Tani Makmur Abadi juga melakukan bentuk pemberdayaan ke anggota kelompok dengan misalnya mengikutkan mereka dalam pelatihan-pelatihan yang diadakan baik dari dinas pertanian maupun pariwisata, hal ini bertujuan untuk adanya perubahan setelah mengikuti pelatihan tersebut dan bisa menerapkan ke pertanian mereka maupun mengelola wisata petik apel.

Rubin dan Rubin (dalam Shragge 2013:22) mengemukakan pengorganisasian masyarakart merupakan membawa orang-orang secara bersama-sama untuk berjuang, berbagai masalah dan mendukung keputusan-keputusan yang mempengaruhi kehidupan mereka.

\section{KESIMPULAN DAN SARAN}

\section{Kesimpulan}

Pembagian kerja di kelompok tani dilakukan oleh ketua berdasarkan kebutuhan dari anggota, dan dalam memasukkan anggota di Kelompok Tani Makmur Abadi dipersilahkan untuk memilih sendiri untuk masuk unit-unit yang ada di kelompok. Diberikannya kebebasan untuk memilih unit-unit sesuai dengan kemampuan dari para anggota kelompok atau petani, hal ini bertujuan untuk lebih memberikan kenyamanan kepada anggota dalam melaksanakan program kerja yang ada di kelompok juga dapat mengelola wisata petik apel lebih baik lagi.

Kepemimpinan yang dilakukan di Kelompok Tani Makmur Abadi adalah yang pertama pemimpin atau Ketua Kelompok Tani Makmur Abadi mengajak para petani melalui pertemuan yang dilakukan dan memberikan penjelasan serta tujuan yang diinginkan kelompok. Proses yang kedua ketua kelompok disini berperan dalam pengambilan suatu keputusan di Kelompok Tani Makmur Abadi, sekalipun tidak selalu ketua yang memutuskan karena dilihat dari tingkat permasalahan yang dihadapi anggota atau petani di Kelompok Tani Makmur Abadi.

Ketua Kelompok Tani Makmur melibatkan anggota kelompok dalam setiap kegiatan berdasarkan pada unit-unit yang mereka masuki. Proses yang terakhir yaitu ketua kelompok 
melakukan kontroling setiap harinya dengan langsung ke lapangan atau ke kebun dan mengawasi setiap kegiatan yang ada di Kelompok Tani Makmur Abadi, selain itu juga membuat pembukuan dan laporan setiap bulannya bahkan setiap tahunnya.

Cara meningktakan keaktifan anggota yang dilakukan Kelompok Tani Makmur Abadi yaitu dengan cara memberikan rangsangan kepada anggota kelompok berupa memberikan bantuan bibit dan mengajak anggota melakukan studi banding ke kelompok lain.

Cara yang kedua yaitu dengan mengikut sertakan anggota kelompok untuk mengikuti pelatihan yang diadakan oleh dinas pertanian maupun dinas pariwisata. Cara yang ketiga yaitu dengan mengadakan pertemuan-pertemuan baik itu secara langsung maupun tidak langsung sekaligus memberikan pengertian dan pengarahan kepada anggota kelompok tani makmur abadi. Cara yang terakhir adalah pengurus sering berkunjung ke kebun petani untuk melihat-melihat perkebunan apel dari petani selain itu juga cara ini dilakukan untuk menjalin komunikasi ke petani dan silaturahim.

\section{Saran}

Berdasarkan simpulan dapat dikemukakan beberapa saran, diharapkan petani lebih sering untuk berkomunikasi dengan kelompok mengenai pertanian apel, petani diharapkan bisa lebih berkontribusi ke kelompok tani.

Bagi Kelompok Tani Makmur Abadi, perlu adanya lagi pelatihan-pelatihan untuk meningkatkan kahlian petani dalam mengelola kebun apelnya, mengundang dinas-dinas untuk memberikan informasi terkait kelompok maupun pertanian, mengadakan lokakarya dan perlu adanya inovasi baru di Kelompok Tani Makmur Abadi dalam mengembangkan kelompok dan mengembangkan wisata petik apel sehingga dapat menjadi rujukan wisata petik apel di kota Batu.
Bagi Jurusan Pendidikan Luar Sekolah, dari penelitian ini diharapkan dapat menjadi bahan rujukan atau bahan ajar mengenai pola pengorganisasian yang dilakukan kelompok dan dapat memperkaya pengetahuan tentang bagaimana mengorganisasi masyarakat untuk mempersiapkan mahasiswa menjadi pendamping desa.

Bagi Penelitian Selanjutnya Perlu penelitian lanjut upaya dari pembentukan Kelompok Tani dalam mempertahankan dan mengembangkan usaha tani bagi pengembangan wisata lanjutan

Dari penelitian ini diharapkan peneliti lain dapat meneliti kelompok-kelompok tani pada aspek lainnya, karena di kelompok-kelompok masih terdapat banyak keunikan dan permasalahan yang dapat di telusuri dan diselesaikan.

\section{DAFTAR RUJUKAN}

Cresswell, J. 2015. Riset Pendidikan: Perencanaan, Pelaksanaan, dan Evaluasi Riset Kualitatif dan Kuantitatif Edisi Kelima. Yogyakarta: Pustaka Pelajar.

Fandeli, C. 2001. Dasar-dasar Manajemen Kepariwisataan Alam. Yogyakarta: Liberty Offset.

Fattah, N. 2013. Landasan Manajemen Pendidikan. Bandung: PT Remaja Rosdakarya.

Hasibuan. 2007. Pembagian Kerja. Jakarta: PT Bumi Aksara.

Setiana, L. 2005. Teknik Penyuluhan dan Pemberdayaan Masyarakat. Bogor: Ghalia Indonesia.

Shragge, E. 2013. Pengorganisasian Masyarakat untuk Perubahan Sosial. Yogyakarta: Graha Ilmu.

Thoha, M. 2013. Kepemimpinan dalam Manajemen. Jakarta: PT. Raja Grafindo.

Ulfatin, N. 2013. Metode Penelitian Kualitatif di Bidang Pendidikan: Teori dan Aplikasinya. Malang: Fakultas Ilmu Pendidikan Universitas Negeri Malang.

Winardi, J. 2003. Teori Organisasi dan Pengorganisasian. Jakarta: PT. Raja Grafindo Persada. 